\title{
Financial and Economic Analyses of Conventional and Reduced Impact Harvesting Systems
}

\author{
Abdul Rahim Abdul Samad \\ Department of Economics, Faculty of Economics \& Management \\ Universiti Putra Malaysia, 43400 Serdang, Selangor, Malaysia \\ E-mail: abrahim@econ.upm.edu.my \\ Mohd Shahwahid $\mathrm{Hj}$. Othman \\ Department of Hospitality \& Recreation, Faculty of Economics \& Management \\ Universiti Putra Malaysia, 43400 Serdang, Selangor, Malaysia \\ E-mail: mohdshahwahid@gmail.com \\ Zariyawati Mohd Ashhari \\ Department of Accounting \& Finance, Faculty of Economics \& Management \\ Universiti Putra Malaysia, 43400 Serdang, Selangor, Malaysia \\ E-mail: zariyawati@econ.upm.edu.my
}

The research is financed by the Fundamental Research Grant Schemes (FRGS) Phase 1/2006, (03-01-07-030FR) provided by the Ministry of Higher Education, Malaysia.

\begin{abstract}
This paper examines the various committed new technology and improve logging activities ascribed in the 'Logfisher' Practice (LP) rather than Conventional Practice (CP). The result of cost analysis shows that the cost constitutes under LP is higher than under CP. Incremental average per ha total cost rose by $46.86 \%$ to RM13,576/ha. While the incremental average per $\mathrm{m}^{3}$ total cost increased by $57.41 \%$ to RM267.80/ $\mathrm{m}^{3}$. Hence, CP was slightly more profitable and exceeds the Net Present Value (NPV) of LP. Similarly, the Benefit-Cost Ration (BCR) for CP is better than LP. On the other hand, the result of the economic analysis of 40-year period showed that the LP system (NPV $=$ RM9302/ha) provided a higher level of overalls benefits and welfare to the society as a whole as opposed to CP (NPV = RM8497/ha).
\end{abstract}

Keywords: Logfisher Practice (LP), Conventional Practice (CP), 'Logfisher', Net Present Value (NPV)

\section{Introduction}

In Peninsular Malaysia, the Dipterocarp Forest of the production forest of the Permanent Forest Estate (PFE) is managed through two management systems, which are the Modified Malayan Uniform System (55-year cutting cycle) and the Selective Management System (30-year cutting cycle). In brief, the Modified Malayan Uniform System consists of removing the mature crop in one single felling of all trees down to $45 \mathrm{~cm}$ diameter at breast height (dbh) for all species while the Selective Management System (SMS) entails the selection of optimum management (felling) regimes based on pre-felling forest inventory data. Forest harvesting in the inland forest in Malaysia is generally carried out by a combination of crawler tractor-winch lorry. Under this harvesting system the crawler tractor skids the logs from the felling sites to the skid trails where the winch lorry continues the transportation to the roadside landings. In Malaysia, the skidder generally does not pick up its load from the felling site because of adverse soil and terrain conditions. In the early nineties, reduced impact logging (ground skidding) was being carried out in some forest areas in Peninsular Malaysia and in the state of Sabah, while low impact logging (helicopter logging) was being carried out in the state of Sarawak (Gan at el., 2006).

The recent technology which is called "Logfisher" has been developed. It was mainly deployed to retrieve logs from rocky and deep narrow ravine which was deemed uneconomical, difficult and dangerous for the crawler tractor to 
undertake. It was gravely introduced as a commercial and viable alternative to other reduced and low impact technologies like Skyline, Mobile Tower Yarder, and Helicopter in the middle of 1999. According to Gan et al. (2006), the New Ground Base Reduced-Impact Logging (NGB RIL) System, featuring a combination of crawler tractor and 'Logfisher' became fully operational in July 1999 in Block C, Compartment 54, Jengai Forest Reserve in the state of Terengganu, Peninsular Malaysia. The site was provided by Kumpulan Pengurusan Kayu-Kayan Terengganu, the largest forest concessionaire in Peninsular Malaysia. Prior to the harvesting operation, planning for the implementation of the system was conducted earlier after careful study and field planning to include marking of trees to be felled and simple tree location mapping.

Availability of more appropriate harvesting cost data can help nations in the planning of the implementation of forest management activities. The knowledge and awareness on the area will influence actions that have potential impacts on financial and economic viability. The purpose of this paper is to present financial and economic costs that incurred in new logging system activities.

\section{Literature Review}

\subsection{Financial and Economic Cost of Logging Operation}

Past studies on logging cost in Malaysia indicated that the average logging cost range from RM117.02/ $\mathrm{m}^{3}$ to RM284.93/ $\mathrm{m}^{3}$ (Ahmad Fauzi et al., 2002; Mohd Shahwahid et al., 1999; Awang Noor \& Mohd Shahwahid, 1997; Lehuji, 2003; Badrul Hisham, 2001; Awang Noor et al., 2007). A study by Mohd Shahwahid et al. (1999) indicated that the average fixed cost constitutes about $83 \%$ of the total logging cost which is RM $237.67 / \mathrm{m}^{3}$. However, it was found that the component of fixed cost in logging operation is relatively lower compared to variable cost component that constitute about $46 \%$ of RM56.98/ $\mathrm{m}^{3}$ of the total logging cost (Badrul Hisham, 2004). In addition, recent studied by Awang Noor et al. (2007) found that the mean total logging cost in Pahang was estimated at RM204.65 $/ \mathrm{m}^{3}$, in which, the fixed cost and the average variable cost comprised at about $53.1 \%\left(\mathrm{RM} 108.63 / \mathrm{m}^{3}\right)$ and $46.9 \%\left(\mathrm{RM} 96.01 / \mathrm{m}^{3}\right)$ respectively. The divergent of fixed and variable cost of logging operation reflects different logging operation, government policy and other factors.

In economic language, the relevant measure is now Total Economic Valuation (TEV) from the different possible land uses. TEV comprises use and non-use values and both are capable of expression in monetary terms by estimating the relevant willingness to pay (WTP) for those function (McNally and Mohd Shahwahid, 2003). The basic argument is that, even if Reduced Impact Logging (RIL) is 'worse' than Conventional Logging (CL) in financial terms, if the WTP for the incremental non-timber benefits of RIL exceeds the financial deficit, RIL will be preferred from a national perspective. For example Dagang et al. (2005) carried out the financial and economics analyses in RIL system by incorporating with several advantages which namely discount rate, harvesting cost, logging intensity of the first harvest, certification premium and carbon transfer payment through sensitivity analysis. At the financial analysis, CL is typically more profitable than RIL but at economic analysis followed by analysing the sensitivity analysis, they found that the RIL system is more profitable and the Net Present Value (NPV) is greater than CL.

\section{2 'Logfisher' Practices in RIL Implementation}

The 'Logfisher' system employs a technique of log extraction which combines the function of winching and lifting, performed by a single machine (Gan et al., 2006). The 'Logfisher' actually embodies the body of an excavator and basic structure of a crane. In the winching operation, a cable rope with a total length of 300 meters is pulled out from the drum and dragged to the respective trees which have been felled in the forest. The open end of the cable rope is then tied and hooked on the felled log.

Gan et al. (2006) has mentioned about the various functions of the crawler tractor in the current conventional and modified ground based RIL in Table 1. Altogether e functions are identified in the conventional system involving 4 processes and over 4 sites. The 4 processes consists of clearing, leveling and cutting of earth; clearing, cutting and blading of earth; winching logs from the forest and skidding to log landing. Meanwhile the four sites are namely; skid trial, log landing, feeder road and main road. In comparison, Table 2 highlights the functions of the crawler tractor and 'Logfisher' in the NGB RIL combining both machines. In this new system, under the 4 similar processes (from process 1 to 4), the crawler tractor functions have been reduced to 4 as compared to the original 8 functions in the current conventional and modified ground based RIL. The 'Logfisher' needs only to conduct one function and an optional two processes involving 4 additional functions are not possible with the current systems using only crawler tractors. Therefore the new system provides a better and more specific distribution of functions best suited to the individual machines in terms of minimal impacts to the environment. The residual stands are best suited in the implementation of RIL. The working sites in the new system have also being reduced from 4 to 3 . Thus further minimising the forest areas to be opened or damaged. The particular site that has become obsolete is the one involves in the construction of skid trials, which apparently is considered as one of the most destructive activities in the current conventional, and modified ground based RIL system. 


\section{Methodology}

\subsection{Costs account}

The analysis will focus on the costs to be incurred with and without compliance to 'Logfisher' activities. The conceptual framework for obtaining the incremental or additional cost of conducting each of the harvesting activities when implementing the 'Logfisher' is shown in Figure 1. Each of these activities occurs within the license time periods. The costs of these activities were compounded to the year harvesting conducted in 2007 as the reference base period.

The combined system is termed as the NGB RIL System and requires only minor adjustment to the current conventional and modified ground based system which utilises only crawler tractor to extract logs from the forest. In the NGB RIL, the crawler tractor undertakes all the previous planned functions involving construction and skidding of logs to temporary log landings. However, log extraction using this system is limited to areas not more than 30-50 meters from the planned roads, beyond which will be carried out by the 'Logfisher'.

This system makes planning much easier and less time consuming by removing the need to plan, mark, measure, map, construct and rehabilitate the extensive network of skid trials associated with the conventional and modified crawler tractor RIL System. The NGB RIL system has been effectively and consistently applied since 1999, incorporating the application of RIL planning procedures and processes in road alignment and construction, marking and mapping of trees to be felled and protected trees, directional felling, marking and mapping of protected areas and buffers in the preparation of a comprehensive harvesting plan.

Cost-benefit analysis was used by two categories. First, the financial analysis was conducted from an enterprise perspective and dealt with actual cash flows. Only traded good and services were considered and valued by applying market prices. Second, the economic analysis was conducted from society perspective. It considered traded and non-traded costs and benefits. Shadow pricing was used to adjust financial costs and benefits to reflect their economic values.

\subsection{Economic Indicators and Sensitivity Analysis}

The economic indicators selected were the net present value (NPV) and the benefit-cost ratio (BCR). A sensitivity analysis was carried out to estimate how changes in key technical and economic parameters would alter the economic performance of the two harvesting systems. The parameters that would probably were considered such as discount rate, timber price, carbon credit, harvesting cost and harvesting volume are adopted from Dagang et al. (2005).

\subsection{Data Collection}

The data for this case study were collected from primary sources. They were provided by the concessionaire from Compartment 220, Sungai Betis Forest Reserve, Gua Musang, Kelantan which under RIL using 'Logfisher' Practice (LP) and in Compartment 109, Nenggiri, Gua Musang, Kelantan which under Conventional Practice (CP). Several types of questionnaires were designed according to the needs for capturing the specific information under this case study. In certain cases, the loggers were also interviewed in seeking for further clarification of data given.

Timber harvesting was conducted using two systems: the LP in a 90-ha research plot and the CP which was conducted in a 100-ha. Table 3 shows the basic characteristics of the study sites. Total timber productions from the LP and CP plots were $4560 \mathrm{~m}^{3}$ and $5430 \mathrm{~m}^{3}$ respectively. Theoretically, both plots were bound by the Selective Method System (SMS). Hence, buffer areas along rivers and steep slopes were marked and protected from harvesting. Thus, the timber volumes not harvested in both the LP and CP plots were $101 \mathrm{~m}^{3}$ and $103 \mathrm{~m}^{3}$ respectively.

For the sensitivity analysis, this study will use the cost of tropical forestry carbon offsets with range about US\$2-10 per ton of carbon, averaging about US\$8 by Stuart \& Costa (1998). In order to account for different economic non-timber forest products (NTFPs) values and biodiversity values under different forest management options, a percentage-based valuation was applied from Sander (2000). For the recreational values, it was assumed that the net operable areas managed under CL have no recreational value. The recreational value on non-production areas was set at RM19 ha/year (Pearce et al., 1999).

\section{Results and Discussion}

Table 4 provides for the present value per hectare cost of harvesting activities conducted at Compartment 220 and 109 under LP and CP options respectively. The overall harvesting present value per hectare costs were RM13,576/ha under LP and RM9,244/ha under CP. This table focuses on distribution of the cost among the pre-felling, felling proper, additional timber harvester activities, and foregone timber revenues.

Additional machine was required to operate the LP activities that are called 'Logfisher'. This took up a big proportion of the total cost. The pre-felling activities comprise of pre-felling inventory of commercial timber trees, compartment boundary demarcation, proposed road alignment, tree tagging and road planning. The cost of pre-felling activities was higher under the CP option (7.24\%) than that under LP option (4.95\%). Tree tagging is usually conducted by a team of 
contract workers who are supervised by a field staff from the Forestry Department and normally the rate charged is $\mathrm{RM} 3 /$ tree tagged.

The felling activities constitute road construction, felling \& bucking, skidding, log loading, short distance haulage, log yard administration, 'Logfisher' premium and royalty and cess. In aggregate, these activities dominated the total harvesting cost under both forest management options taking up $66.07 \%$ under LP and $83.15 \%$ under CP. Payments for premiums and royalty and cess charges, skidding and administration which includes margin of profit for the contractor were the major cost elements. Cost of road construction was low under CP (14.83\%) but high under LP (30.51\%) owing to the need to follow road specification. This had caused the need for additional rental of 'Logfisher' and longer work time to abide to the more rigid road specification listed in the RIL technique.

This specification considers environmental impacts by minimizing movements of heavy equipment in the stand, minimizing the construction of non-permanent feeder roads and cable log trails without soil protection structures, optimizing the lay-out of feeder road and cable log trails, and properly compact and shape road camber. The use of excavator rather than bulldozer in the road formation cut is to reduce unnecessary road corridors and to prevent excessive blading of the soil. In the LP area, the road density was quite high at $60 \mathrm{~m} / \mathrm{ha}$ but the advantage of this practice was there is no need for skid trails. On the other hand, in the $\mathrm{CP}$ area, the road density was only within the $40 \mathrm{~m} /$ ha but there is skid trails at $300 \mathrm{~m} / \mathrm{ha}$ (refer Table 3 ).

The above elements alluded on direct financial transaction costs. The licensee, contractors and harvesting crews incurred opportunity cost from unearned timber income from buffer areas. The average production cost only rose by 9.35\% to RM14,975/ha when the foregone timber revenue from buffer areas were included in the LP option. Conversely, the average production cost increased by $13.96 \%$ to RM10,744/ha with the inclusion of these foregone revenues in the $\mathrm{CP}$ option. The opportunity cost is computed as potential gross revenue net of direct cost of extraction. These foregone revenues comprised of foregone timber revenue incurred by the licensee and loss of royalty charges not collected by the Government.

Table 5 shows the harvesting cost on per cubic meter basis. Similar trends were observed as on a per hectare basis. This information is useful as the timber harvesting industry is more familiar in measuring financial viability in terms of per volume units. The costs of harvesting were RM295.44/ $\mathrm{m}^{3}$ and RM197.76/ $\mathrm{m}^{3}$ under LP and CP options respectively.

It was observed that the per hectare present value costs of harvesting activities were consistently higher under LP than $\mathrm{CP}$ option mainly due to greater expenditures on improved activities. The incremental proportions of the cost among the various activities were more varied particularly in road construction and 'Logfisher' machine. However, there is zero cost in skidding activity due to the absence of that activity in LP option. In aggregate, compliance to the LP led to an overall increase of RM4330.47/ha or $46.88 \%$ and RM97.67/ $\mathrm{m}^{3}$ or $57.41 \%$ (Table 6 ).

The higher percentage of increase in terms of per cubic meter under LP option in comparison to the CP option is due to the lower timber yield productivity that raised the average cost. Among the various activities, the increase was only $0.92 \%$ or RM1/ha in pre-felling activities; $82.08 \%$ or RM1459.37/ha in felling activities and RM3045.33/ha in additional machine of 'Logfisher' (Table 6). The activities with significant incremental costs were road construction and 'Logfisher' machine.

This analysis indicates that complying to the LP for RIL technique lead to an additional cost. The additional cost of shifting from one harvesting practice to another is a burden to the company. The incidence of this burden has been computed in this paper. Consideration of compensation may have to be addressed explicitly to encourage compliance if improved conservation and sustainability of the forest is to be achieved. Instruments of financing these compensations have to be determined.

LP in RIL implementation is an essential element for sustainable forest management of the tropical forest. Therefore, ecological impacts of logging need to be mitigated using economically competitive technology. The context of LP in RIL system has been clearly demonstrated. Felling efficiency can be improved to enable significant reduction of environmental damage especially when there is no skidding activity during the operation. Despite these benefits, full adoption of RIL system in the context of LP in Peninsular Malaysia's forest concessions, still have not been widely accepted.

\subsection{Financial Analysis}

Table 7 indicates that the total profit of CP and LP is at RM49/ $\mathrm{m}^{3}$ and $-\mathrm{RM} 66 / \mathrm{m}^{3}$ respectively in a one-year period. At this point of time, the timber producers will loss because of higher cost and lower revenue in LP option compared to CP option. The lower revenue in LP option was due to the buffer areas and stringent criteria's implemented in their logging activities. For the financial analysis for 40 -year period, the NPV and BCR indicate that both management options are profitable (Table 8). CP was slightly more profitable and exceeds the NPV of LP. Similarly, the BCR for CP exceeds the NPV of LP. This means that with regard to the private profitability preference which relies more on financial analysis, it implies $\mathrm{CP}$ is more robust. 


\subsection{Economic Analysis}

The economic analysis of 40-year period showed that the LP system (NPV = RM9302/ha) provided a higher level of overalls benefits and welfare to the society as a whole as opposed to CP (NPV = RM8497/ha). The result of the sensitivity analysis demonstrated that LP was more profitable than CP if;

a) A discount rate of less that three percent is applied; or

b) The harvesting costs are reduced by $>30$ percent; or

c) The timber price increases by $>15$ percent; or

d) A minimum of RM30/ha of annual carbon trading payments are generated.

The results demonstrate that the LP system is more profitable if the harvesting cost reduced by 10 percent and that the logging intensity during the first cut is increased by 20 percent. Assuming that the concessionaire receives additional revenue of RM15/ha/yr through carbon credit payments, the NPV under LP would increase to RM737, i.e. a $26 \%$ percent increase over the CP system.

\section{Conclusions}

This study has described the cost of logging in Kelantan and calculated the two different cost of logging methods namely 'Logfisher' and conventional logging. The results of the study shows that the cost constitutes under LP is higher than under CP. Incremental average per ha total cost rose by $46.8 \%$ to RM13,573/ha. While the incremental average per $\mathrm{m}^{3}$ total cost increased by $57.4 \%$ to RM $267.80 / \mathrm{m}^{3}$. With the increasing fuel prices and other cost related to labour, the logging cost is expected to increase in the near future. This situation will have adverse affect on the profitability of the practice of sustainable forest management.

The sensitivity of the economic analysis indicates that in the long run, a slight reduction of the harvesting cost and other incentive systems such as price premium, carbon credit, overalls benefits and welfare to the society as a whole can also help to facilitate the introduction of LP option. These findings are consistence with Dagang et al. (2005) which found that at the financial analysis, CL is typically more profitable than RIL but at economic analysis they found that the RIL system is more profitable. Hence the Malaysian Timber Council (MTC), Malaysian Timber Certification Council (MTCC) and International Tropical Timber Organisation (ITTO) have a role to play to promote such timber markets and non-timber markets among its consuming nation members.

\section{References}

Ahmad Fauzi, P., Salleh, M., Mohd Shahwahid, H.O., Abdul Rahim, N. Awang Noor, A.G. \& Muhamad Farid, A.R. (2002). Cost of Harvesting Operations in Compliance with ITTO Guidelines. In N. Abdul Rahim (ed.), A Model Project for Cost Analysis to Achieve Sustainable Forest Management. Volume II: Main Report. Frim/ITTO, Kuala Lumpur, Malaysia. Pp. 63-84.

Awang Noor, A.G. \& Mohd Shahwahid, H.O. (1997). Forest Valuation Methodology. Malaysia AIFM Pilot Project Final Report. Chin Tuck Yuan, Mohd. Hizamri Mohd Yassin and Kasinatahan Kengaih (Eds.) AIFM, Kuala Lumpur, Malaysia.

Awang Noor, A.G., Mohd Syauke, M.S. \& Tuan Marina, T.I. (2007). Analysis of Logging Cost in Pahang. Paper Presented at the Seminar on Economic Valuation of Forest Goods and Services 2007, December 15-18, 2007, Kuala Terengganu, Terengganu, Malaysia.

Badrul Hisham, K. (2004). Cost and Earning Structure of Logging Industry in the State of Sabah. M.S. Project Report. Faculty of Forestry, University Putra Malaysia, Serdang, Selangor, Malaysia.

Borhan, M. \& Guglhor, W. (1998). Development of Reduced-Impact Logging Methods/Techniques in the Project Area. Paper presented at the Workshop on the Malaysian-German Sustainable Forest Management and Conservation Project in Peninsular Malaysia. Forest Research Institute Malaysia (FRIM), Kepong, Kuala Lumpur. Paper No. 11.

Borhan, M. \& Johari, B. (1982). The Effects of Logging in a Mixed Dipterocarp Forest in Peninsular Malaysia. Paper Presented at the Eighth Malaysian Forestry Conference, Sandakan, Sabah, Malaysia.

Dagang, A.A., Richter, F., Hahn-Schillng, B. \& Manggil, P. (2005). Financial and Economic analyses of Conventional and Reduced Impact Harvesting Systems in Sarawak. Pp. 236-251 in Enters, et al. (Eds.) International Conference Proceedings on Applying Reduced Impact Logging to Advance Sustainable Forest Management, 26 February to 01 March 2001, Kuching Sarawak, Malaysia.

Gan, B.K., Amir Abdul Nasir, S. \& Zulkifli, A. (2006). The Logfisher - Its Development and Application in a New Ground-Based Reduce-Impact Logging System in Peninsular Malaysia. Proceeding of the ITTO - MoF Regional Workshop on RIL Implementation in Indonesia with Reference to Asia-Pacific Region: Review and Experience, 15-16 February 2006, Bogor, Indonesia, pp. 137-145. 
Lehuji, P.L. (2001). Stumpage Valuation of Compartment 40, Deramakot Forest Reserve, Sabah. M.S. Project Report. Faculty of Forestry, University Putra Malaysia Serdang, Selangor, Malaysia.

McNally, R. \& Mohd Shahwahid, H.O. (2003). Environmental Economics. A Practical Guide. WWF-UK and Universiti Putra Malaysia.

Mohd Shahwahid, H.O. Awang Noor, A.G., Abdul Rahman, M.D. \& Shaharuddin Ahmad. (1999). Cost and Earning Structure of Logging Industry in Peninsular Malaysia. The Malayan Forester, 62, 107-117.

Pearce, D., Putz, F. \& Vanclay, J.K. (1999). A Sustainable Forest Future. Centre for Social and Economic Research of the Global Environment (CSERGE) Working Paper GEC 99-15. Center for Social and Economic Research on the Global Environment, University of East Anglia, Norwich.

Sander, K. (2000). Financial and Economic Analysis of Forest Management Systems at FOMISS-Samling Pilot Area (FSPA). Consultancy Report No. 52. Malaysian-German Technical Cooperation Project. Forestry Department of Sarawak and Forest Management Information System Sarawak (FOMISS): Kuching, Malaysia.

Stuart, M.D. \& Moura Costa, P. (1998). Climate Change Mitigation by Forestry: A Review of International Initiatives. Policy that Works for Forests and People. Series no. 8. Discussion paper. International Institute for Environment and Development: London, UK.

Table 1. The Crawler Tractor in the Current Conventional and Modified Ground Based RIL Logging System

\begin{tabular}{|l|c|c|c|c|}
\hline \multirow{2}{*}{ Processes } & \multicolumn{4}{|c|}{ Sites } \\
\cline { 2 - 5 } & Skid trail & Log landing & Feeder road & Main road \\
\hline $\begin{array}{c}\text { 1. Clearing, leveling and } \\
\text { cutting of earth }\end{array}$ & Crawler Tractor & Crawler Tractor & Crawler Tractor & Crawler Tractor \\
\hline $\begin{array}{c}\text { 2. Clearing, cutting and } \\
\text { blading of earth }\end{array}$ & Crawler Tractor & NIL & NIL & NIL \\
\hline $\begin{array}{c}\text { 3. Winching logs from } \\
\text { The forest }\end{array}$ & Crawler Tractor \\
\hline $\begin{array}{c}\text { 4. Skidding to log } \\
\text { Landing }\end{array}$ & Crawler Tractor & NIL & NIL & NIL \\
\hline
\end{tabular}

Source: Gan et al. (2006)

Table 2. The Functions of Crawler Tractor and 'Logfisher' in the NGB RIL Logging System

\begin{tabular}{|l|c|c|c|}
\hline \multirow{2}{*}{ Processes } & \multicolumn{2}{c|}{ Sites } \\
\cline { 2 - 4 } & Log landing & Feeder road & Main road \\
\hline 1. Clearing, leveling and Cutting of earth & $\begin{array}{c}\text { Crawler } \\
\text { Tractor }\end{array}$ & $\begin{array}{c}\text { Crawler } \\
\text { Tractor }\end{array}$ & Crawler Tractor \\
\hline 2. Clearing, cutting And blading of earth & NIL & NIL & NIL \\
\hline 3. Winching logs from the forest & NIL & NIL & NIL \\
\hline $\begin{array}{l}\text { 4. Skidding to log Landing } \\
\text { N. Construction of bridges and culverts }\end{array}$ & NIL & $\begin{array}{c}\text { Crawler } \\
\text { Tractor }\end{array}$ & NIL \\
\hline $\begin{array}{l}\text { 6. Stacking of logs along feeder road and } \\
\text { log landing }\end{array}$ & 'Logfisher' & 'Logfisher' & 'Logfisher' \\
\hline
\end{tabular}

Source: Gan et al. (2006) 
Table 3. Summary of Study Sites

\begin{tabular}{|l|c|c|}
\hline \multicolumn{1}{|c|}{ Options } & $\begin{array}{c}\text { 'Logfisher' Practice } \\
\text { (LP) }\end{array}$ & $\begin{array}{c}\text { Conventional } \\
\text { Practice (CP) }\end{array}$ \\
\hline Area (ha) & 90 & 100 \\
\hline Buffer and protected area (ha) & 2 & 3 \\
\hline Net production area (ha) & 88 & 97 \\
\hline Volume of harvest $\left(\mathrm{m}^{3}\right)$ & 4560 & 5430 \\
\hline Volume of harvest per ha (m ${ }^{3} /$ ha) & 50.7 & 54.3 \\
\hline Volume of commercial timber not harvested from buffer area $\left(\mathrm{m}^{3}\right)$ & 101 & 103 \\
\hline Road density $(\mathrm{m} / \mathrm{ha})$ & 60 & 40 \\
\hline Skid trail(m/ha) & 0 & 300 \\
\hline
\end{tabular}

Table 4. Per Hectare Average Present Value Cost of Harvesting Activities

\begin{tabular}{|l|c|c|c|c|}
\hline \multicolumn{1}{|c|}{ Activities } & \multicolumn{2}{c|}{ LP } & \multicolumn{2}{c|}{ CP } \\
\cline { 2 - 5 } & RM/ha & $\%$ & RM /ha & 7.24 \\
\hline $\begin{array}{l}\text { Pre-felling } \\
\text { Pre-felling inventory of trees, boundary, road } \\
\text { alignment, tree tagging and road planning. }\end{array}$ & 670 & 4.95 & 669 & \\
\hline $\begin{array}{l}\text { Felling } \\
\text { Road construction, felling \& bucking, skidding, } \\
\text { log loading, short distance haulage, log yard } \\
\text { administration, royalty, cess and premium }\end{array}$ & 8970 & 66.07 & 7639 & 83.15 \\
\hline 'Logfisher' & & & & \\
\hline Others & & & & 0 \\
\hline Total & 3049 & 22.43 & & 10.11 \\
\hline Foregone revenue from buffer areas & 890 & 6.56 & 936 & 100 \\
\hline Grand total & 13576 & 100 & 9244 & 13.96 \\
\hline
\end{tabular}

Table 5. Average Total Cost of Harvesting Activities per Cubic Meter Timber Production

\begin{tabular}{|c|c|c|c|c|}
\hline \multirow{2}{*}{ Activities } & \multicolumn{2}{|c|}{ LP } & \multicolumn{2}{|c|}{$\mathrm{CP}$} \\
\hline & $\mathrm{RM} / \mathrm{m}^{3}$ & $\%$ & $\mathrm{RM} / \mathrm{m}^{3}$ & $\%$ \\
\hline $\begin{array}{l}\text { Pre-felling } \\
\text { Pre-felling inventory of trees, boundary, road } \\
\text { alignment, tree tagging and road planning. }\end{array}$ & 13.21 & 4.9 & 12.32 & 7.24 \\
\hline $\begin{array}{l}\text { Felling } \\
\text { Road construction, felling \& bucking, skidding, } \\
\text { log loading, short distance haulage, log yard } \\
\text { administration, royalty, cess and premium }\end{array}$ & 176.91 & 66.06 & 140.68 & 82.69 \\
\hline 'Logfisher' & 60.11 & 22.44 & 0 & 0 \\
\hline Others & 17.57 & 6.56 & 17.23 & 10.12 \\
\hline Total & 267.80 & 100 & 170.13 & 100 \\
\hline Foregone revenue from buffer areas & 27.63 & 9.35 & 27.62 & 13.96 \\
\hline Grand total & 295.44 & 100 & 197.76 & 100 \\
\hline
\end{tabular}


Table 6. Average Changes in Cost by Compliance to New Logging System Activities

\begin{tabular}{|c|c|c|c|c|}
\hline \multirow[b]{2}{*}{ Activities } & \multicolumn{2}{|c|}{ LP } & \multicolumn{2}{|c|}{ LP } \\
\hline & $\mathrm{RM} / \mathrm{ha}$ & $\begin{array}{c}\% \\
\text { increase }\end{array}$ & $\mathrm{RM} / \mathrm{m}^{3}$ & $\begin{array}{c}\% \\
\text { increase }\end{array}$ \\
\hline $\begin{array}{l}\text { Pre-felling } \\
\text { Pre-felling inventory of trees, boundary, road } \\
\text { alignment, tree tagging and road planning. }\end{array}$ & 1 & 0.15 & 0.89 & 7.22 \\
\hline $\begin{array}{l}\text { Felling } \\
\text { Road construction, felling \& bucking, skidding, } \\
\text { log loading, short distance haulage, log yard } \\
\text { administration, royalty, cess and premium }\end{array}$ & 1331 & 17.42 & 36.23 & 2.57 \\
\hline 'Logfisher' & 3049 & 22.44 & 60.11 & 0 \\
\hline Others & (46) & $(4.9)$ & 0.34 & 1.97 \\
\hline Total & 4332 & 46.86 & 97.67 & 57.41 \\
\hline Foregone revenue from buffer areas & $(100)$ & $(6.67)$ & 0.01 & 0.03 \\
\hline Grand total & 4231 & 39.38 & 97.68 & 49.39 \\
\hline
\end{tabular}

Table 7. Cost and Revenue for Harvesting Systems in a One-year Period

\begin{tabular}{|l|c|c|}
\hline \multirow{2}{*}{\multicolumn{1}{c|}{ Parameter }} & CP & LP \\
\cline { 2 - 3 } & \multicolumn{2}{|c|}{$\left[\mathrm{RM} / \mathrm{m}^{3}\right]$} \\
\hline Cost - harvesting & 170 & 267 \\
\hline Revenue - timber & 219 & 201 \\
\hline Total profit & 49 & $(66)$ \\
\hline
\end{tabular}

Table 8. Indicators for Financial Analysis of Harvesting Systems*

\begin{tabular}{|c|c|c|c|}
\hline \multicolumn{2}{|c|}{ NPV $(\mathrm{RM})$} & \multicolumn{2}{c|}{ BCR } \\
\hline CP & LP & CP & LP \\
\hline 584 & 311 & 1.4 & 0.9 \\
\hline
\end{tabular}

$*$ Notes: Discount rate $-8 \%$, calculation period -40 years, production area $=1$

Table 9. NPV of Harvesting Systems After Incorporating with RIL/LP Benefits

\begin{tabular}{|l|l|l|l|l|}
\hline No. & Parameter & Unit & CP & LP \\
\hline 1 & Discount rate & {$[\%]$} & - & $10(10)$ \\
\hline 2 & Harvesting costs & {$[\%]$} & - & -10 \\
\hline 3 & Price premium & {$[\%]$} & - & $10(10)$ \\
\hline 4 & Carbon credit & {$[\mathrm{RM} / \mathrm{ha} / \mathrm{yr}]$} & - & $15(0)$ \\
\hline 5 & Logging intensity of the first harvest & {$[\mathrm{m} / \mathrm{ha}]$} & $33.3(27.8)$ & $33.3(27.8)$ \\
\hline & NPV & {$[\mathbf{R M} / \mathbf{h a}]$} & $\mathbf{5 8 4}$ & $\mathbf{7 3 7}$ \\
\hline
\end{tabular}

Notes: () refer to original values used for the cost-benefit analysis

Minus 10 in relation to original harvesting costs used in the cost-benefit analysis 


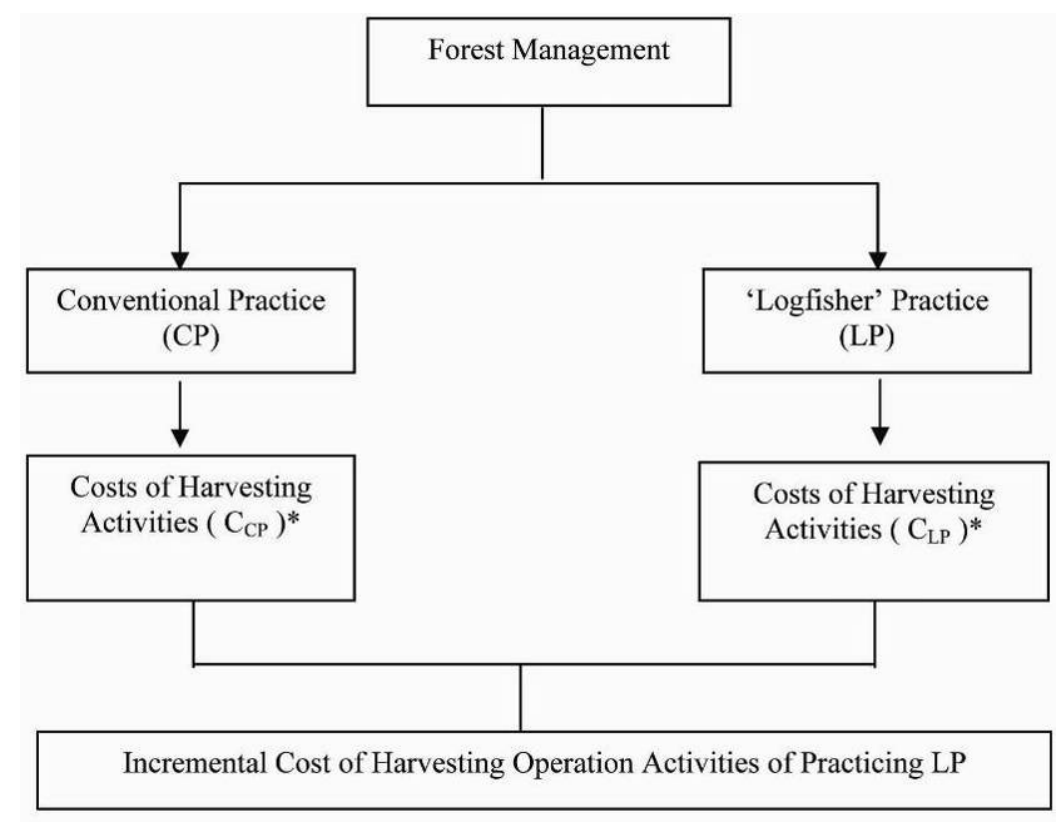

Figure 1. Analytical Framework of Cost Analysis for Harvesting Operations**

$$
\text { Aggregate Incremental Cost of Complying to } L P=\sum_{j} C_{j} /(1+r)^{t}-\sum C_{i} /(1+r)^{t}
$$

where;

$\mathrm{C}_{\mathrm{i}}$ and $\mathrm{C}_{\mathrm{j}}$ are costs of harvesting activities under $\mathrm{CP}$ and LP respectively.

$r$ is the interest rate.

$t$ is the year of activity.

Activities include harvesting plan, pre-felling, delineation of compartment boundary and proposed road alignment, tree tagging and 'Logfisher' machine.

* are the identified activities conducted under both CP and LP options.

** are adapted and modified from Ahmad Fauzi et al. (2002)

$\mathrm{i}, \mathrm{j}$ are various itemized activities and $m, n$ are the total number of these activities respectively.

Net present value $(N P V)=\Sigma\left(B^{t}-C^{t}\right) /(1+i)^{t}$

where;

$$
\begin{aligned}
B^{t} & =\text { Benefit/Revenue for year } \mathrm{t} \\
\mathrm{C}^{\mathrm{t}} & =\text { Cost for year } \mathrm{t} \\
\mathrm{i} & =\text { interest } \\
\mathrm{t} & =\text { year }
\end{aligned}
$$

Benefit cost ratio $(\mathrm{B} / \mathrm{C})=\Sigma\left\{\mathrm{B}^{\mathrm{t}} /(1+\mathrm{i})^{\mathrm{t}}\right\} / \Sigma\left\{\mathrm{C}^{\mathrm{t}} /(1+\mathrm{i})^{\mathrm{t}}\right\}$

where;

$$
\begin{aligned}
\mathrm{B}^{\mathrm{t}} & =\text { Benefit/Revenue for year } \mathrm{t} \\
\mathrm{C}^{\mathrm{t}} & =\text { Cost for year } \mathrm{t} \\
\mathrm{i} & =\text { interest } \\
\mathrm{t} & =\text { year }
\end{aligned}
$$

